\title{
Combating Unemployment through Social Entrepreneurship in the European Context
}

\author{
http://doi.org/10.21272/bel.4(4).85-98.2020
}

Loredana Nicoleta Zainea, ORCID: https://orcid.org/0000-0002-7743-8217

PhD Student, Doctoral School of Management, The Bucharest University of Economic Studies, Bucharest, Romania

Sorin-George Toma, ORCID: https://orcid.org/0000-0001-9116-7751

$\mathrm{PhD}$, Professor, Faculty of Administration and Business, University of Bucharest, Bucharest, Romania

Paul Marinescu, ORCID: https://orcid.org/0000-0003-1006-0974

$\mathrm{PhD}$, Professor, Faculty of Administration and Business, University of Bucharest, Bucharest, Romania

Andreea Chițimiea, ORCID: https://orcid.org/0000-0003-1390-639X

PhD Student, Doctoral School of Management, The Bucharest University of Economic Studies, Bucharest, Romania

\begin{abstract}
Consideration of the dynamic changes from the socio-economic environment, social entrepreneurship plays an essential role in the labour market as it creates new jobs, contributes to the improvement of the economic and social position of vulnerable groups in society, and stimulates economic development. The financial crisis from 2008 and the current health crisis, which generated a significant economic crisis and the specific social context existing in each member state, constitute the leading causes that led to a slow convergence rhythm of the labour market at the European Union level. Unemployment and non-employment have a significant impact on the people affected by poverty and the disadvantaged people. A coherent, systematic and sustainable approach to social entrepreneurship is required to generate significant change at the European level. Innovative solutions to current economic, social and environmental challenges are needed since the private or/and public sectors do not fully meet the communities' existing needs. The aim of the paper is to analyze how social entrepreneurship contributes to the reduction of the unemployment rate, by meeting the objectives set out in the Europe 2020 Strategy, to create a sustainable and inclusive social market economy, and to improve social cohesion. The quantitative method, based on the data found in various international journals, statistical reports and electronic databases, was used by the authors to accomplish the objective of the paper. The paper illustrates that social entrepreneurship is a complex process in which resources are used in an efficiently and effectively way, new skills, competences, and knowledge are accumulated, which turn into social and economic innovation, having a positive impact on productivity and the creation of highly skilled jobs, as well as maximizing the opportunities which lead to social change.
\end{abstract}

Keywords: Social Entrepreneurship, Unemployment, European Union, Education.

JEL Classification: L31, E24, I2.

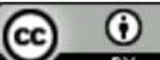

Cite as: Zainea, L.N., Toma, S.G., Marinescu, P., Chițimiea, A. (2020). Combating Unemployment Through Social Entrepreneurship in the European Context. Business Ethics and Leadership, 4(4), 85-98. http://doi.org/10.21272/bel.4(4).85-98.2020.

(C) The Authors, 2020. This article is published with open access at Sumy State University.

\section{Introduction}

In the last years, there has been a gap between labour supply and economic development due to such multiple drivers, as technological disruption, territorial mobility, migration, and "skill mismatches, which arise primarily for lack of work experience and appropriate work-related skills of individuals" (Cedefop, 2015), leading to negative consequences on the economic competitiveness and the continuation of the financial convergence process (European Commission, 2018). It is said that "technological change does not just destroy jobs, but also generates new ones through its effect on productivity and the demand for new technologies" 
(OECD, 2017). One of the main challenges is that "technological changes demand higher skills and qualifications, which might not be fully met by current labour supply, given the time necessary for the education and training system to adjust" (European Commission, 2020a). Due to the rapid development of technologies, "the skills sought by employers are different from the skills offered by job-seekers" (European Commission, 2017), disparities appear, often associated with structural unemployment. Also, "the economic and political conditions in the short and long run have a major influence on labour market" (International Labour Organization, 2020). Several scenarios have been designed concerning the labour market challenges (Cedefop, 2016). To reduce the harmful effects of unemployment, it is imperative to create professional retraining programs aimed at facilitating the individual's insertion into the labour market, including those belonging to vulnerable groups, and to implement public policies aimed at strengthening the link between employment and social protection. In the meantime, public and private policies designed for entrepreneurship imply all stakeholders' involvement, the creation and permanent updating of the labour market dynamics databases, and the use of the latest financial instruments. In this respect, "several issues such as poverty and human welfare have motivated various firms to conduct business with an embedded social drive" (Huda et al., 2019). The Europe 2020 strategy set out targets in five areas, namely employment, education, research \& development, poverty and social exclusion, climate change and energy to achieve the objective of "increasing productivity and competitiveness and creating a sustainable social market economy" (European Commission, 2010):

$>75 \%$ of people aged between 20 and 64 should be working;

$>$ to reduce below $10 \%$ the share of school dropout, and at least $40 \%$ of people aged $30-34$ to complete tertiary education;

$>$ to invest $3 \%$ of GDP in the R\&D sector;

$>$ to reduce the number of people at risk of poverty and social exclusion by 20 million;

to reduce greenhouse gas emissions by 20\% compared to 1990 .

The member countries have set their own goals "in accordance with the local conditions and possibilities, which are integrated into the European strategy" (Zainea et al., 2019). Entrepreneurship contributes to economic and social development worldwide (Toma et al., 2014). During this time, social entrepreneurship, a category of entrepreneurship, has proved to be a viable solution to diminish unemployment (OECD, 2013) and a driver for improving the quality of life (Zainea et al., 2020), starting from the fact that the values, history and culture of the local communities' members are the basis of the social entrepreneurship initiatives. As "every organization needs one core competence: innovation" (Drucker, 2011), social entrepreneurship leads to social and economic change through "technological innovations that create jobs and unleash opportunities for launching new firms that regenerate the economy" (Baumol, 2010). Since the current health crisis leads to the economic crisis, social inequalities amplification, unemployment increase and a reduced capacity to predict the necessary skills and competencies required on the labour market, it is necessary to update the existing economic and social models or design new ones following current realities. The paper aims to briefly analyze how social entrepreneurship contributes to reducing the unemployment rate in European countries. The structure of the article is as follows: the next section deals with the literature review. The research methodology is presented in the third part of the paper and is followed by results and discussions. The article ends with conclusions.

\section{Literature Review}

Unemployment. Unemployment represents one of the most severe socio-economic problems of our time. A simple definition of unemployment is to "class someone as unemployed if they are able and willing to work, but cannot find a job" (Atkinson, 1998). International Labour Organization (2019) defines unemployment as "all persons aged 15 or above, who were not employed, carried out activities to seek employment during a specified recent period, respectively the last four weeks or one month, and were currently available to take up employment given a job opportunity". According to the economic point of view, the unemployment is an "unused labour supply" (International Labour Organization, 2019). The labour market evolution can be analysed based on the following indicators: unemployment rate, employment and vacancies. On the one hand, the unemployment increase harms individuals due to revenues decrease, and on the other hand on the state budget, in terms of tax revenues reduction and implicitly minimizes the government expenses for social services. Combating unemployment constitutes an essential issue of the policy agenda all over the world, and, therefore, identifying solutions related to this aspect is vital to ensuring the well-being of the people.

Social Entrepreneurship. In the past years, there was research regarding social entrepreneurship and social enterprise (Saebi et al. 2018; Shaw \& de Bruin, 2013), which highlighted that these concepts differ from traditional entrepreneurship and enterprise, having as a primary goal to create social value, rather than personal 
benefits (Noruzi et al., 2010; Phillips et al., 2014). As a "sub-discipline of entrepreneurship" (Austin et al., 2006), social entrepreneurship "has emerged as a new label for describing the work of the community, voluntary and public organizations, as well as private firms, working for social rather than for-profit objectives" (Shaw \& Carter, 2007). As an emerging research and practice (Gupta et al., 2020; Okpara \& Halkias, 2011), social entrepreneurship interconnects with other concepts, such as corporate social responsibility, social innovation, charity, volunteering, etc. Social entrepreneurship is an "essentially contested concept" (Choi \& Majumdar, 2014), although it is an area of significant interest, which has created various debates among researchers that have not led to an unanimously accepted definition. In the absence of a consensus definition, sizing, and key features of this concept, the social entrepreneurship operationalization in the empirical literature is very different, as follows:

$>$ "the creation of viable socio-economic structures, relations, institutions, organizations and practices that yield and sustain social benefits" (Fowler, 2000);

$>$ "combines the passion of a social mission with an image of business-like discipline, innovation, and determination" (Dees, 2001).

$>$ "creates innovative solutions to immediate social problems and mobilizes the ideas, capacities, resources and social arrangements required for long-term, sustainable, social transformations (Letts et al., 2003)";

$>$ "is about channeling entrepreneurial activity towards solving social problems" (Corner \& Ho, 2010);

$>$ "represents the recognition, formation, evaluation, and exploitation of opportunities to create new businesses, models and solutions with a focus on achieving blended value" (Zahra et al., 2014).

The definitions mentioned above show that social entrepreneurship combines the entrepreneurial activities with the satisfaction of solving social problems and identifies the opportunities that can lead to new business models, and implicitly, new jobs. "The particular organizational form of a social enterprise should be a decision that would most effectively mobilize the resources needed to address that social problem" (Austin et al., 2006), and the strategy implementation should be done in a transparent and socially responsible way, by involving all actors directly implicated or the ones affected by this activity, respectively employees, clients, shareholders, etc. Within this process, various relationships, collaborations, and structures are created. Also, suitable solutions are identified, which may lead to the sustainable development of society. Supporting the employees' development process by acquiring new skills and qualifications is an example of how social innovation, "the key to social entrepreneurship" (Abeysekera, 2019), responds to the unmet or future social needs. In other words, social entrepreneurship might be called the "quiet revolution" (Forbes, 2019), because it contributes to the economic and social transformation, and if as many organizations as possible will replicate this business model, it may have a positive impact on the social change pace.

As change agents, social entrepreneurs should be innovative (Pangriya, 2019; Tan et al., 2005) and use the latest instruments, methods, techniques, and business models to "resolve pressing social problems through their vision, desire, capability, and zeal" (Kabir, 2019). In conclusion, it can be stated that through social entrepreneurship, various benefits can be obtained at the individual level, such as acquiring new skills and competences, enlarging the network of friends, gaining an honorary position in society (Agermann \& Sittermann, 2010), increasing self-esteem and minimize the risk of discrimination and marginalization. At the societal level, social entrepreneurship responds to the current economic and social challenges, positively influences the community well-being, as it solves several social problems (e.g., unemployment), assisting in developing a competitive social economy, diminishes poverty and exclusion, and contributes to social cohesion. Job creation is one means by which social entrepreneurship fights unemployment. In this respect, various studies have emphasized the positive role social entrepreneurship plays in combating and reducing unemployment in the last decades (Nolan \& Coghlan, 2002; OECD, 2013; Rahim \& Lajin, 2015; Carraher et al., 2016).

\section{Research Methodology}

The authors used a descriptive and quantitative research method since it describes the main features and the link between the two concepts considered, respectively, unemployment and social entrepreneurship, to achieve the goal of the article. The literature review was carried-on through comprehensive research, based on multiple information found in international journals (e.g., Entrepreneurship: Theory and Practice, Work, Employment and Society, Journal of Economic Literature, International Entrepreneurship and Management Journal), articles and books from various databases (e.g., Science Direct, Sage Journals, Google Scholar, Springer, ProQuest, Emerald Insight), as well as in European statistics (e.g., Eurostat statistics explained, European Commission, OECD). The data were meticulously selected and grouped into categories. Then, they were analyzed, correlated, and synthesized. Finally, the authors designed and wrote the article. 


\section{Results and Discussions}

According to Eurostat statistics, in December 2019, the EU-28 registered an unemployment rate of 6.2\%, and in the euro area (EA - 19), an unemployment rate of 7.4\%. As it can be seen (Fig. 1), in December 2019, the lowest unemployment rates were registered in Czechia (2.0\%), followed by Germany and the Netherlands (3.2\%). On the other hand, the highest unemployment rates were recorded in Greece (16.6\% in October 2019) and Spain (13.7\%). In Romania, the unemployment rate registered in December 2019 was $4.0 \%$.

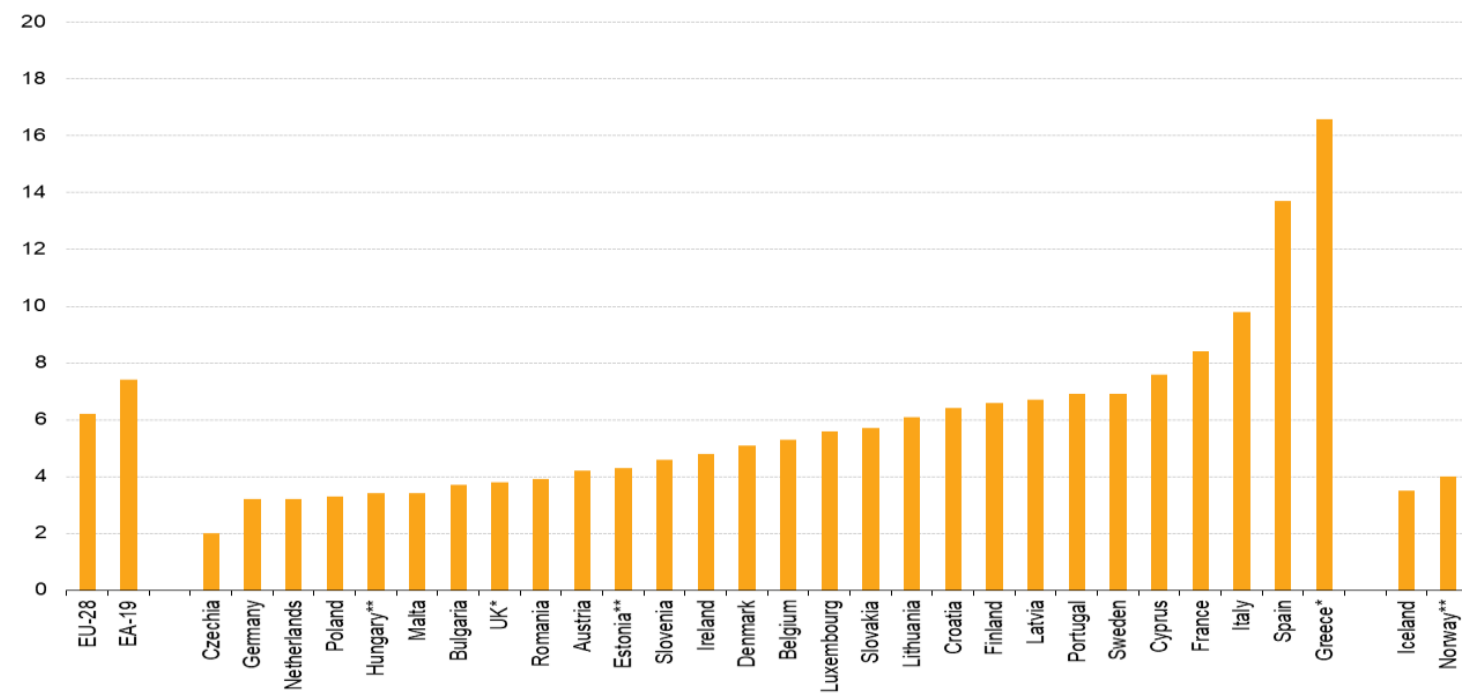

Figure 1. Unemployment Rates, Seasonally Adjusted, December 2019

Note: *October 2019, **November 2019

Source: Eurostat statistics explained, 2020

Compared to 2018, the unemployment rate decreased in $21 \mathrm{EU}$ member states. The most significant changes were registered in Greece (from $18.5 \%$ to $16.6 \%$ ), Croatia (from $7.3 \%$ to $6.4 \%$ ), and Bulgaria (from $4.7 \%$ to $3.7 \%$ ). At the opposite pole, the unemployment rate increased in Cyprus (from 7.4\% to 7.6\%), Portugal (from 6.6\% to $6.9 \%$ ), Sweden (from $6.5 \%$ to $6.9 \%$ ), Lithuania (from $5.8 \%$ to $6.1 \%$ ), Luxembourg (from $5.2 \%$ to $5.6 \%$ ) and Slovenia (from $4.4 \%$ to $4.6 \%$ ), while in Denmark remained constant. "The degree of a skills mismatch between labour supply and demand represents the existing gap in the labour market" (Cedefop, 2018). We mention two methods to measure the existing labour market. They are the "analysis of wages" (Green, 2016) since their level shows an upward trend in many economic sectors, and the Beveridge curve analysis, known as the "unemployment-vacancy jobs curve, which predicts the job search process efficiency, as well as how the increasing number of job vacancies will lead to a proportional employment increase" (Layard et al., 2005). "The Beveridge curve highlights the negative relationship between unemployment and job vacancies" (Elsby et al., 2015). Usually, during crises when the economy contracts, the unemployment rate increase and job vacancies are limited. At the time of economic expansion, the unemployment rate decreases, and the number of job vacancies increases.

Figure 2 shows the Beveridge curves for 2006 - 2019, in the EU - 27 and the euro area (EA - 19). The labour market has undergone significant changes, materialized in the increase of the unemployment rate and the job vacancies, due to the economic-financial crisis from 2008. The significant external change highlighted in the Beveridge curves between 2010 and 2013, especially between 2010 and 2011, emphasizes the differences between the member states, by the fact that the countries that registered a low unemployment rate, there were many job vacancies. The curve changes in both areas, namely EU - 27 and EA - 19, are visible since 2014 and are determined by the employment rates increase on the background of the unemployment rates reduction. 


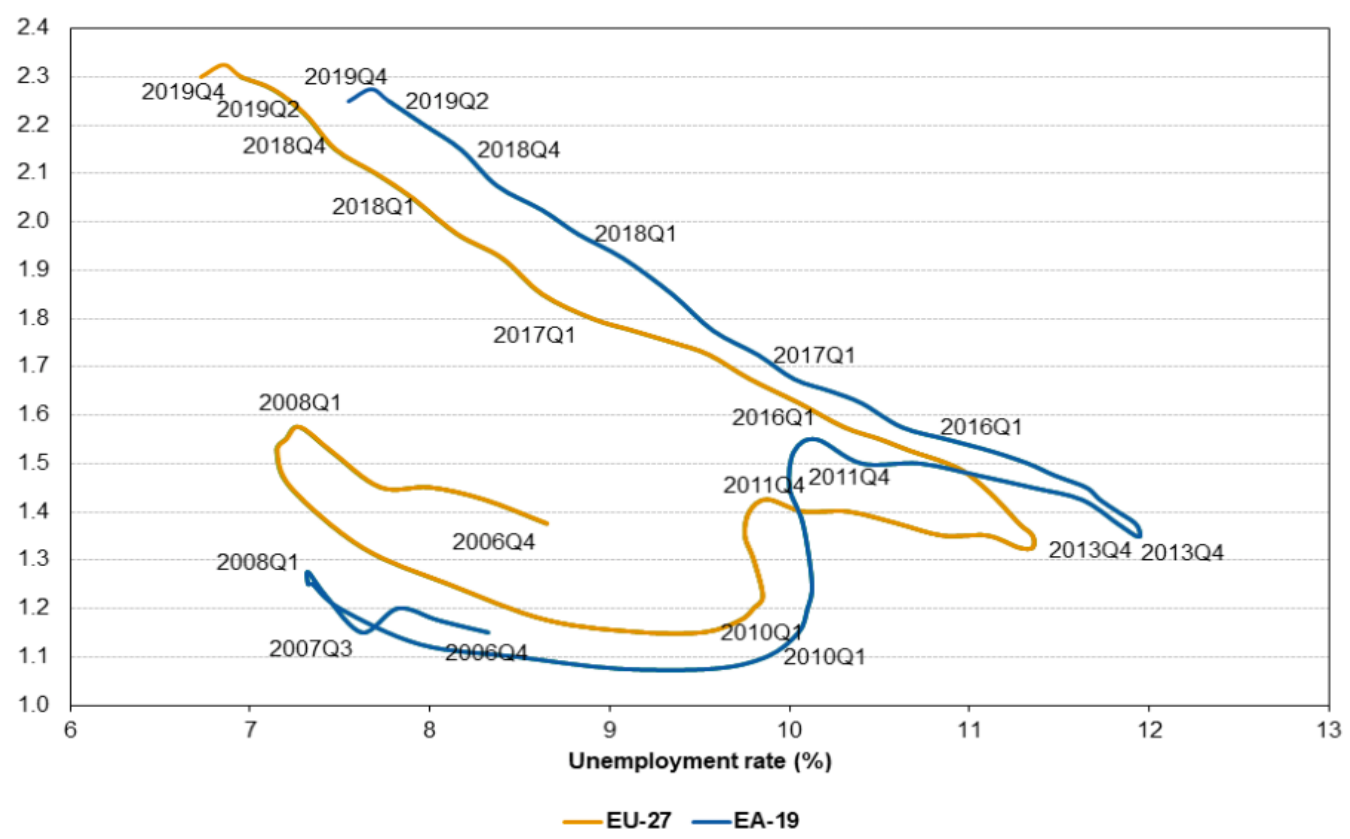

Figure 2. Beveridge Curve, 2006q4 to 2019q4 (four-quarter average rates)

Source: Eurostat statistics explained, 2020

Under the conditions of a "functioning labour market, an increase of the job vacancies number will lead to a proportional decrease in unemployment" (Walper, 2003). The unemployment, respectively that phenomenon caused by the lack of perspective in finding a suitable job, have a significant impact on people affected by poverty or those with health issues, on vulnerable groups, from which we mention NEET people, individuals with disabilities, persons over 50 years old, national minorities, as well as those with a low educational level, etc.

\section{Ways of Combating the Unemployment through Social Entrepreneurship}

How does Social Entrepreneurship Fight Unemployment? Social entrepreneurship represents, on the one hand, a topic of significant interest for both researchers and practitioners, and on the other hand, "is highly contested due to the numerous organizations involved in its conceptualization, such as NGOs, governments, individuals, not-for-profit (NFP) organizations and private businesses" (Hossain et al., 2017). "Both for-profit and social entrepreneurship requires creativity and innovation, however, in the social context, this is manifested mainly in managerial actions by applying novel solutions to intractable social problems" (Shaw \& Carter, 2007). Social entrepreneurship is a key factor for approaching the economic, social and environmental challenges, and social enterprises, as instruments of social inclusion and labour integration, can contribute to reducing unemployment through various ways, as follows:

1. Providing Jobs. Social entrepreneurship is an innovative activity, the purpose of which is to increase the well-being of individuals and communities and the number of jobs by benefiting from the advantages of the „European single market. It influences enterprises' economic growth, productivity, and competitiveness in the context of globalization, energy policies, environment, transport, circular economy, etc. It allows European citizens to travel, learn, work" (Zainea et al., 2019). According to Eurostat statistics (2020), out of the total number of enterprises, a percentage of $99.5 \%$ is represented by small and medium enterprises (including social enterprises), which comprise two-thirds of total employment. "As key drivers of innovation, job creation and economic growth, firms of any size can and should contribute to economic well-being and social progress" (Hoek, 2018). Figure 3 shows the distribution of the total jobs in Europe in 2017, by categories of enterprises, small, medium and large enterprises. The labour force is distributed, in a proportion between $40 \%$ and $60 \%$, in small enterprises. 


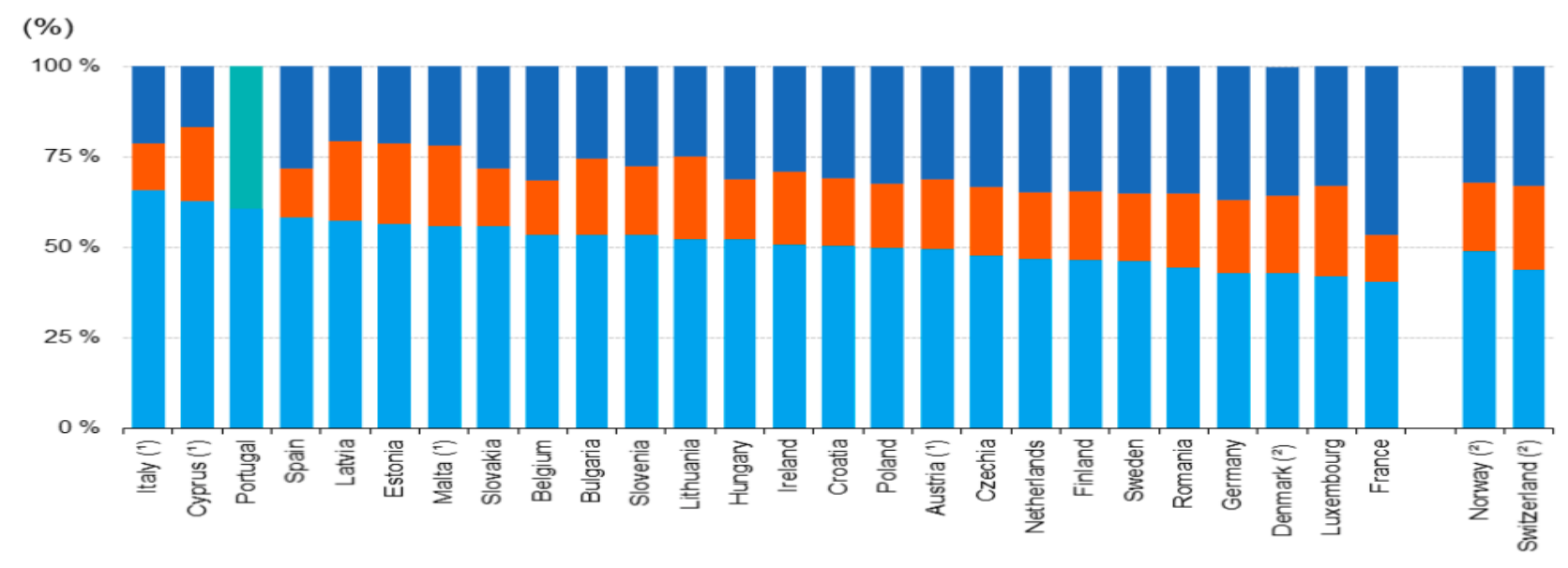

= Small (0-49) = Medium (50-249) = Large (250+) = Medium+Large

Figure 3. Distribution of Employment by Enterprise Size Class, 2017 (\%)

Note: Data for Greece is not available, (1) Data for 2017 was replaced by 2016 data, (2) Data for 2017 was replaced by 2015 data Source: Eurostat statistics explained, 2020

The social organization's mission is to integrate disadvantaged people into the labour market by:

offering to the employees emotionally support;

$>$ establishing a strong and lasting relationships between the company, its customers and its employees, based on trust and mutual respect;

$>$ investing in human capital;

$>$ ensuring a favourable organizational climate that stimulates the level of involvement, job satisfaction, loyalty for the company, the feeling of belonging to a team.

European social enterprises contribute to achieving key policy objectives, such as job creation, civic engagement and social cohesion. The total number of social enterprises varies across Europe from tens of thousands (e.g., France, Germany, Italy, the United Kingdom) to a few hundred (e.g., Albania, Croatia, Denmark, Estonia). Data on employment in social enterprises show that (European Commission, 2020b):

$>$ the number of employees varies but most of these enterprises are micro- and small firms;

$>$ female workers are in a high proportion.

In the last years, the estimated number of employees in social enterprises ranges from around 1.2 million in France, more than 890,000 in Italy and more than 570,000 in Belgium to 1.600 in Estonia (European Commission, 2020b).

2. Creating and Developing New Skills for Employees. To access information, education, or various cultural opportunities, in an increasingly globalized and digitalized society, it is necessary to "develop new skills and competencies that stimulate employability" (Cornali \& Tirocchi, 2012) to ensure inclusive growth and increase competitiveness in the European space. Improving social skills and professional competences of employees in social enterprises are based on an integrated approach, which consists of:

$>$ counselling and vocational training programs, entrepreneurial education based on social entrepreneurship and social innovation;

$>$ educational, artistic and cultural programs, having the scope to stimulate creativity, intercultural dialogue between various people, groups or communities, and help to identify social roles;

$>$ using modern methods, techniques and tools for implementing and monitoring activities, as well as risk management to avoid undesirable situations;

$>$ supporting digital education, as it is one of the modern ways of disseminating good practice, necessary for successful integration into the digital world;

$>$ facilitating dialogue and solidarity between generations to accelerate positive social change.

There are several ways of combating and reducing unemployment through education in general and entrepreneurship education. According to the dictionary, "education" represents a fundamental social phenomenon of transmitting adult generations' life experience and culture to the younger generations, empowering them to integrate into society, good manners, and social behaviour standards (DEX, 2020). "The existence of any modern and progressive society can never be imagined without education" (Ahmed, 2015). According to UNESCO, OECD, and Eurostat (2018), formal education and training represent "that education which is institutionalized, intentional, planned and provided by recognized public and private organizations 
and - in their totality - constitutes the formal education system of a country". From the life quality point of view, education can be seen as a "lifelong learning process" (Blossfeld \& von Maurice, 2011) measured through the acquired skills, abilities and competencies. An individual's level of education is the highest level of education completed. Education levels are classified by (UNESCO, 2012) as follows:

"low: ISCED 0-2 (under primary, primary and lower secondary education);

medium: ISCED 3 and 4 (upper secondary education and non-tertiary post-secondary education);

$>$ high: ISCED 5 - 8 (tertiary education)".

As can be seen below (Fig. 4), in 2018, people aged between 25 and 64 who have completed a tertiary level of tertiary education represent $32.3 \%$ of the EU-28 population, and $45.8 \%$ of people have completed an upper secondary or non-tertiary post-secondary education.

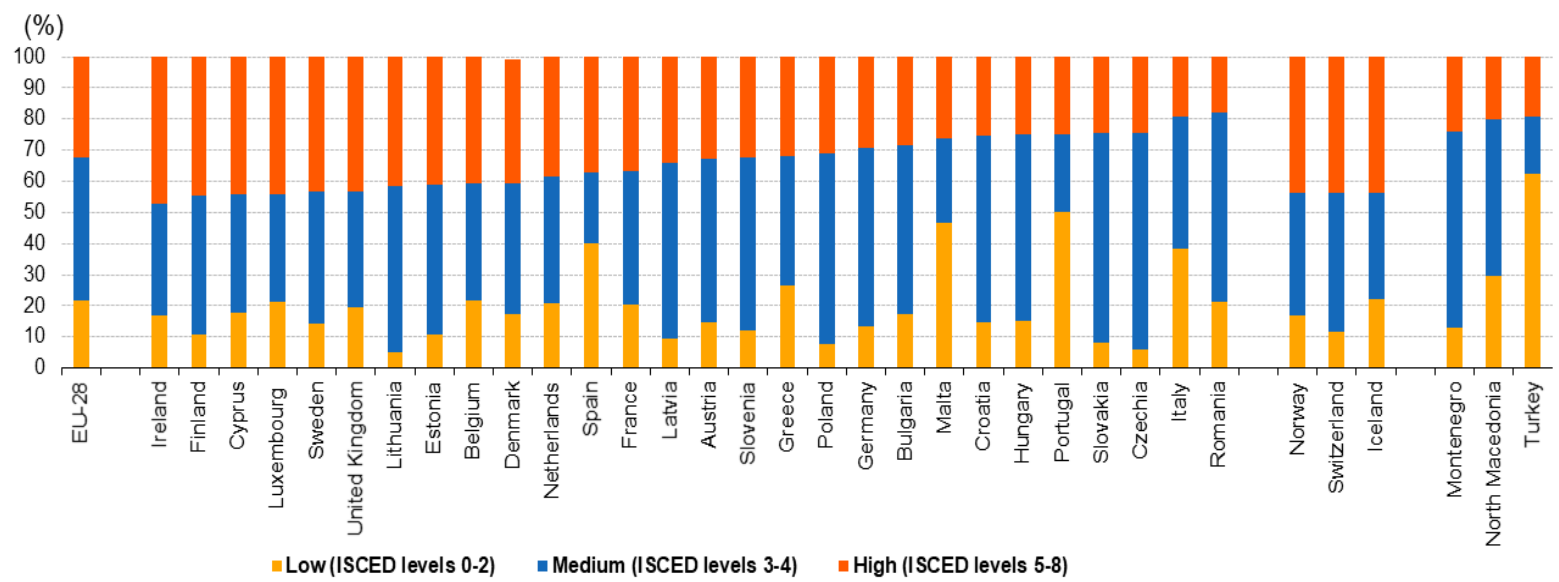

Figure 4. Distribution of the Population Aged 25-64 Years by Level of Educational Attainment, 2018 (\%)

Source: Eurostat statistics explained, 2020

In 2018, the distribution of the population aged between 25 and 64 splits by the level of educational attainment was as follows:

$>\quad$ in the southern member states, the share of those who have completed a low education level (ISCED 0-2) was between $26.4 \%$ in Greece and $50.2 \%$ in Portugal;

$>\quad$ in the eastern member states (Romania, Poland, Czechia and Slovakia), the population share with a medium level of education (ISCED 3-4) was over 60\%;

$>\quad$ in the western or northern member states, the population share who have completed a high education level (ISCED 5-8) is at least two-fifths (Ireland, Finland, Cyprus, Luxembourg, Sweden, the United Kingdom, Lithuania, Estonia and Belgium); the smallest proportions, less than a fifth of the total population, were registered in Romania and Italy.

Figure 5 shows the share evolution of the population with tertiary education level in the EU-28, aged 25-64, between 2008 and 2018, registering an increase of $8.3 \%$, respectively, from $24.2 \%$ to $32.5 \%$. The lowest increase was recorded in Germany, from $25.4 \%$ in 2008 to $29.1 \%$ in 2018, and the highest increase was recorded in Luxembourg, from $27.7 \%$ in 2008 to $44.1 \%$ in 2018.

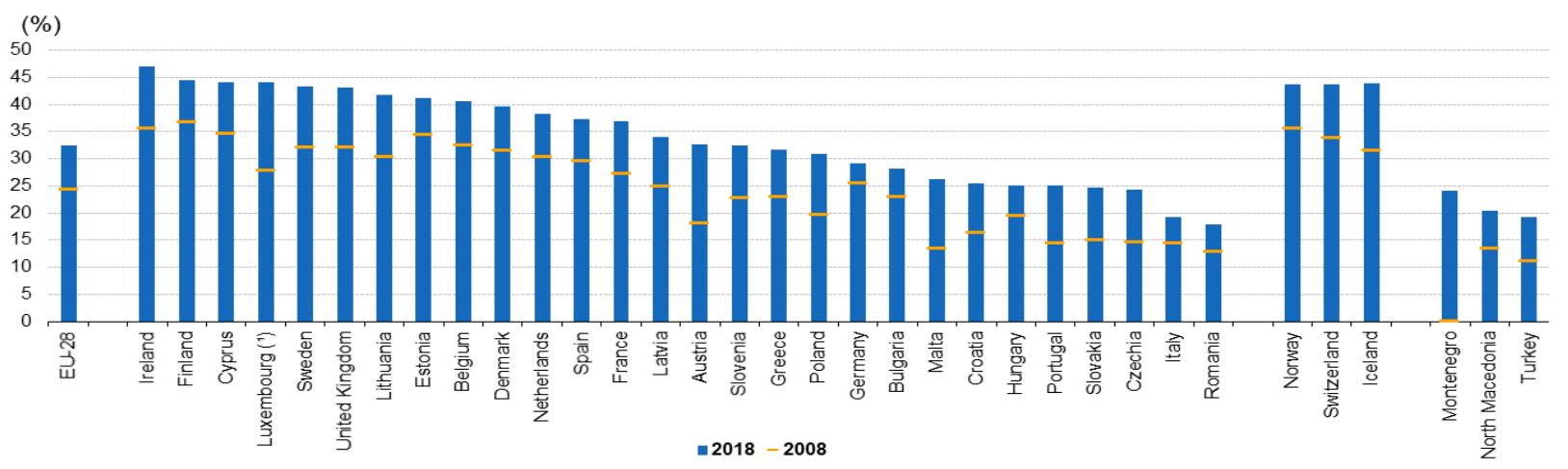

Figure 5. Proportion of the Population Aged 25-64 Years with a Tertiary Level of Educational Attainment, 2008 and 2018 (\%) Source: Eurostat statistics explained, 2020 
In 2018, according to Eurostat statistics (2020) related to the education level attainment, in the EU-28, the unemployment rate was higher for low educational training level and even lower for high education levels. Thus, people aged between 15 and 74 with a high education level were at risk of unemployment at $4.1 \%$, while people with a low education level were three times more at risk, respectively $13.3 \%$. In Czechia, Slovakia, Hungary, Bulgaria and Lithuania, the ratio between unemployment rates for people who have completed a high and low education level was higher, while in Portugal, Greece and Cyprus was lower. As per Eurostat statistics (2019), in the EU-28, in 2017, the population aged 16 to 74, who had at least a basic level of digital literacy $-57 \%$. However, there are significant digital differences between member states. Thereby, in Romania and Bulgaria, only $29 \%$ of the population have basic digital skills, while in Ireland, Latvia, Greece, Croatia, Poland and Italy the share is between $40 \%$ and $50 \%$. Luxembourg has registered the highest population share aged 16 to 74 with at least basic digital skills, respectively $85 \%$. The education level has increased in recent years, as well as the demand for highly degreed people (Ghaffarzadegan et al., 2017), and "the educational achievement is crucial to occupational status attainment" (Edgerton et al., 2012). Education has a major and positive impact on people's quality of life, in the sense that people with disabilities or belonging to vulnerable groups have lower employment rates than the general population and weaker economic prospects (Ballo, 2019). Those who leave school early are subject to the risk of social exclusion and civic life participation is restricted. The mentioned aspects lead to the necessary proactive measures, respectively:

$>$ involving all social partners in the elaboration of adequate public policies;

$>$ increasing investments and the level of public spending on education;

$>$ reducing the rate of early school leaving;

$>$ improving lifelong learning;

$>$ development of counselling and career guidance services;

$>$ development of an application that integrates the educational system and vocational training with the economic environment;

$>$ strengthening social cohesion by promoting multilingualism and intercultural dialogue in the European space.

Finally, the author can state that people with a high level of education have better employment prospects and the possibility of obtaining higher incomes, aspects that positively influence their quality of life. The current young generation has a high level of education and a highly skilled workforce that will successfully replace the older generation. In today's "knowledge-based economy, education is fundamental" (Pârgaru et al., 2009) and represent the basis of human civilization as it transmits the knowledge gained from one generation to another, the engine of technological innovation that contributes to economic growth, as the number of educated people reflects the degree of development of the relationship between education and the workforce. As an "essential activity in the development of society" (Pârgaru et al., 2009), education facilitates the insertion into the labour market, the involvement in various civic and political actions, "reduces the risk of social exclusion and poverty" (Slijepcevic, 2016), improves people's understanding of the world in which they live and inoculates them with the feeling that they can influence it. Entrepreneurship education seeks to provide pupils and students from primary or secondary schools and universities the abilities, skills (e.g., risk-taking, problemsolving), and knowledge needed to stimulate their entrepreneurial mindset. Developing entrepreneurship education in schools, vocational institutions, and universities will positively impact the entrepreneurship dynamics nature in our economies (European Commission, 2014). New teaching and learning methods are required, from pre-school to higher education, and "all young people should benefit from at least one practical entrepreneurial experience before leaving compulsory education" to adapt the education system to the current challenges. (European Commission, 2012). Apart from the skills, competencies and knowledge provided by entrepreneurship education, social entrepreneurship education puts the accent on other and new ones as follows (Brock \& Steiner, 2009):

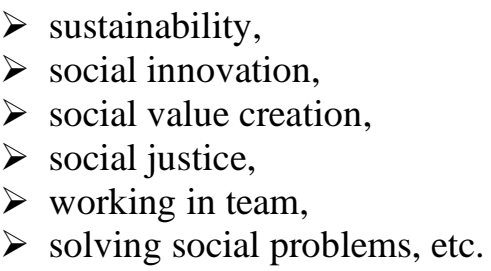

Thus, social entrepreneurship education is critical for society as it contributes to job creation (Mars, et al., 2008), focuses on social change (Nicholls, 2006) and promotes social justice (Waghid \& Oliver, 2017).

3. Generating New Jobs through Social Innovation. Technological progress, globalization, and increasing competitiveness influence daily life, and the demand for highly skilled jobs and new competencies is 
accelerating. On the one hand, companies must increase their productivity and show flexibility in the relationship with the employees, customers and stakeholders; on the other hand, entrepreneurs "whether in the business or social realm, must accept the fact that innovation is not a one-time event but continues overtime" to meet the challenges of the competitive environment, (Noruzi et al., 2010). Social innovation can be defined as "innovative activities and services that are motivated by the goal of meeting a social need" (Mulgan, 2006). Social innovation is a specific characteristic of social entrepreneurship. The OECD differentiates it from economic innovation, noting that "it is not about introducing new types of production or exploiting new markets in themselves but is about satisfying new needs not provided for by the market (even if markets intervene later) or creating new, more satisfactory ways of insertion in terms of giving people a place and a role in production" (OECD, 2010). According to (Martínez-Torres, 2014), social innovation "should be understood as a fruit of interactions among social actors, individuals, and communities." "A central role in the economic development is played by high growth enterprises, as these enterprises typically account for around $15 \%$ of the total persons employed in the business sector" (Eurostat statistics explained, 2020). High growth enterprises are those enterprises that meet certain specific conditions, namely, to have an average annual increase in employment of more than $10 \%$ over three years and to employ at least ten people at the beginning of the growth. Usually, high growth enterprises are micro and small enterprises, which brings them even closer to the concept of entrepreneurship and social entrepreneurship, where innovation represents the „key driver in organizational success" (McCann \& Ortega-Argiles, 2013).

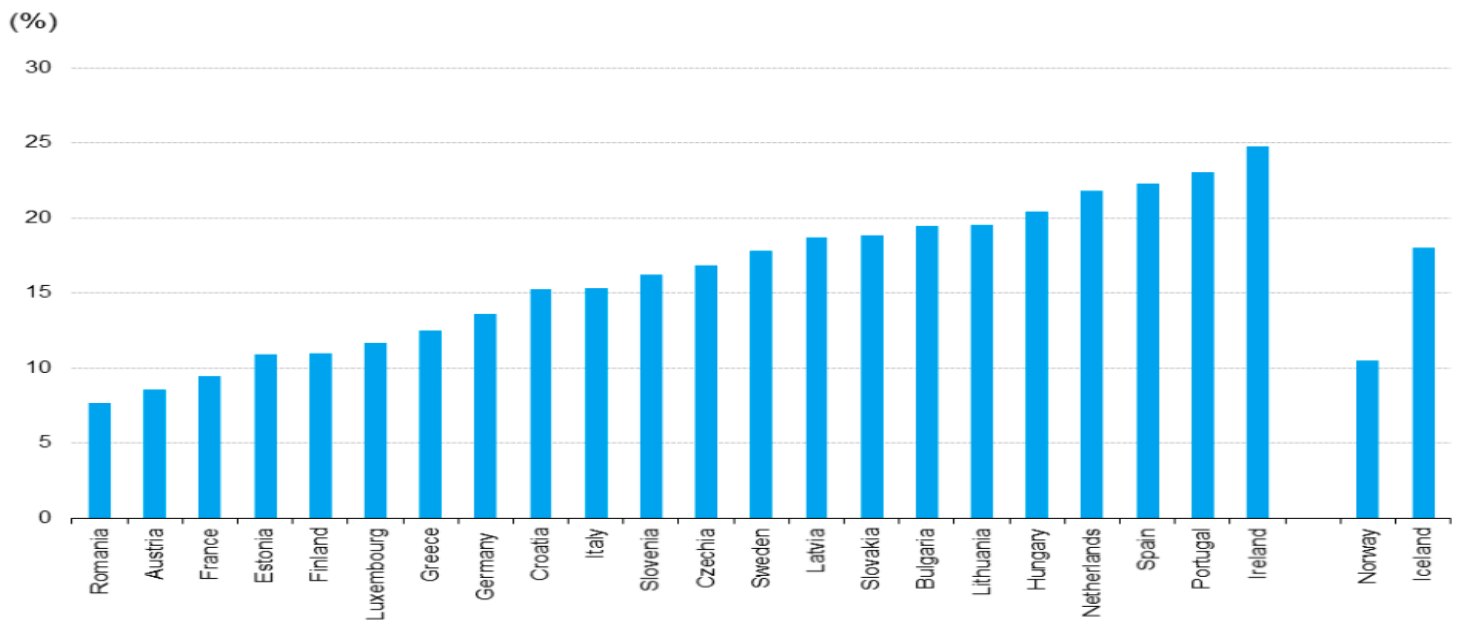

Figure 6. The Employment Share of High Growth Enterprises in 2017 (\%)

Note: provisional data for Austria, Greece, Iceland; data not available for Belgium, Denmark, Cyprus, Malta and Poland Source: Eurostat statistics explained, 2020

According to Eurostat data presented above (Fig. 6), in 2017, high-growth enterprises had an essential contribution to employment in Europe, between $8 \%$ in Romania and $24.7 \%$ in Ireland. "Social entrepreneurship can be seen as either a mere slideshow to the mainstream economic activities of the society and/or something radically transformative of that very system. These different viewpoints can range from asking how we make existing society better to a more fundamental asking of what sort of society do we want" (Newey, 2018).

\section{Conclusions}

A coherent, systematic and sustainable approach to social entrepreneurship is required to generate significant change at the European level. Innovative solutions to current economic, social and environmental challenges are needed since the private or/and public sectors do not fully meet the communities' existing needs. Social entrepreneurship is a growing field with a positive impact on communities. The dissemination of good practice models in EU member states can develop European and national policies that reduce constraints and effectively support social innovators and entrepreneurs. From a practical point of view, some possible ways to strengthen the social entrepreneurship sector at national, regional, and European levels are as follows:

1. Promoting social entrepreneurship to raise awareness of the concept importance, as well as the positive and immediate benefits to the community, through schools and universities, at all levels of education, by:

introducing specific disciplines, given the multidisciplinary nature of the concept to develop entrepreneurial and digital skills to facilitate the insertion of disadvantaged people into the labor market;

$>$ supporting mobility in the European space for educational purposes (e.g., Erasmus Program);

$>$ developing mentoring and coaching programs on career guidance through modern educational and emotional approaches; 
$>$ participation in various collaborative activities;

$>$ social networks or online platforms (e.g., euromentor.eu), useful tools, which provide information based on the know-how and experience of specialists in the field, as well as on how individuals can get involved in social causes;

$>$ European and national authorities and institutions in international exchanges of experience.

2. Public dialogues and debates with all actors in the field, including national and European institutions, on the one hand to involve in the social sector as investors in social affairs or as social entrepreneurs and the assimilation of common socially responsible values and principles, and on the other another hand, having the scope to adapt the legislation to current socio-economic requirements.

3. Facilitate the financial access for social enterprises, using modern financial instruments and the development of coherent strategies at national and European level since donations, public subsidies or the sale of products and services do not cover all needs.

However, the most effective way to transfer good practices is to empathize with each other, to share our values, motivations, and visions. In this paper, the authors combined the theoretical and conceptual analysis of social entrepreneurship and unemployment with practical ways to combat unemployment and, based on the correlation analysis, the impact of these two concepts on the quality of life of individuals and the labor market was studied, which led to the following conclusions. Firstly, this article highlights the relationship between social entrepreneurship and education, their interconnection with the labor market, and the fact that there are concrete ways in which these two concepts can contribute to reducing the unemployment rate to create a sustainable and inclusive social market economy. Secondly, the article emphasizes that social entrepreneurship combats unemployment by providing jobs, developing new skills and competencies in line with labor market requirements, and social innovation, which is an ongoing process and not an isolated event. Social entrepreneurship also promotes creativity, solidarity, equality in diversity, local traditions, a sustainable way of life and social cohesion. Thirdly, given the growing demand for highly skilled jobs in today's knowledgebased economy, education is the engine of technological innovation. It contributes to economic growth and facilitates labor market entry, reduces the risk of social exclusion and poverty, improves people's ability to understand the world in which they live and inoculates them with the feeling that they can influence it. Fourthly, the article highlights the significant impact that unemployment has on people affected by poverty or those with health problems, vulnerable groups, and people with a low education level.

Also, some scientific research has shown that the use of advanced technologies in the field of information and communications, robotics, or digitization of large-scale production, led to an increased unemployment rate. Finally, in the context of dynamic changes in the socio-economic environment, the integration of disadvantaged people into the labor market, respectively the population category with specific problems and the most exposed at risk, is a challenge for all EU member states, and social entrepreneurship is one of the viable solutions, as it offers benefits at both individual and societal level. At the individual level, the benefits consist of providing jobs, developing new skills, increasing self-esteem, reducing the risk of discrimination and marginalization. At the societal level, social entrepreneurship responds to current economic and social challenges, positively influences the well-being of the community, helps to develop a competitive social economy, fights unemployment, poverty and exclusion, and contributes to territorial cohesion.

Author Contributions. Conceptualization, Loredana Nicoleta Zainea; literature review, Sorin-GeorgeToma; methodology, Sorin-George Toma, Paul Marinescu and Andreea Chițimiea; formal analysis, Loredana Nicoleta Zainea; writing, original draft, Loredana Nicoleta Zainea; writing, review and editing, Sorin-George Toma, Paul Marinescu and Andreea Chițimiea; project and administration, Loredana Nicoleta Zainea and Sorin-George Toma; supervision, Loredana Nicoleta Zainea, Sorin-George Toma and Paul Marinescu. All authors have read and agreed to the published version of the manuscript.

Funding. This research was funded solely by the authors.

\section{References}

1. Abeysekera, R. (2019). Social entrepreneurship: concepts and research areas. Sri Lanka Journal of Management Studies, 1(2), 29-42, Available at: https://www.researchgate.net/publication/339575370_SOCIAL_ENTREPRENEURSHIP_CONCEPTS_ AND RESEARCH AREAS.

2. Agermann, A., \& Sittermann, B. (2010). Volunteering in the European Union - An Overview. Sociopolitical Developments in Europe, pp. 2. Available at: http://www.sociopoliticalobservatory.eu/uploads/tx aebgppublications/Working_Papier no 2 Observatory Volunteering in the EU_Overview.pdf. 
3. Ahmed, S. (2015). Education: Traditional Vs. Modern Perspective. American Research Journal of English and Literature, 1(2), 1-4. Available at: https://www.researchgate.net/publication/333755333 Education Traditional Vs Modern Perspective.

4. Atkinson, B. (1998). Unemployment. In: Atkinson B., Livesey F., Milward B. (Eds.) Applied Economics. London: Palgrave, p. 386. https://doi.org/10.1007/978-1-349-14250-7_23.

5. Austin, J., Stevenson, H., \& Wei-Skillern, J. (2006). Social and commercial entrepreneurship: Same, different, or both? Entrepreneurship: Theory and Practice, 30(1), 1-22. https://doi.org/10.1111/j.15406520.2006.00107.x.

6. Ballo, J.G. (2019). Labour Market Participation for Young People with Disabilities: The Impact of Gender and Higher Education. Work, Employment and Society, 34(2), 336-355. https://doi.org/10.1177/0950017019868139.

7. Baumol, W.J. (2010). The microtheory of innovative entrepreneurship. New Jersey, NJ: Princeton University Press, p. 37, ISBN: 9780691145846. Available at: https://press.princeton.edu/books/ebook/9781400835225/the-microtheory-of-innovative-entrepreneurship.

8. Blossfeld, H.P., \& von Maurice, J. (2011). Education as a lifelong process. Educational science ( $Z$ Erziehungswiss), 14(1), 19-34, DOI 10.1007/s11618-011-0179-2.

9. Brock, D. D. \& Steiner, S. D. (2009). Social entrepreneurship education: Is it achieving the desired aims? DOI: http://dx.doi.org/10.2139/ssrn.1344419.

10.Carraher, S.M., Welsh, D. H. B., \& Svilokos, A. (2016). Validation of a measure of social entrepreneurship. European Journal of International Management, 10(4), 385-402. Available at: https://www.inderscienceonline.com/doi/pdf/10.1504/EJIM.2016.077421.

11.Cedefop (2015). Skill shortages and gaps in European enterprises: Striking a balance between vocational education and training and the labour market. Luxembourg: Publications Office of the European Union, p. 7. Available at: https://www.cedefop.europa.eu/files/3071_en.pdf.

12.Cedefop (2016). Future skill needs in Europe: critical labour force trends. Luxembourg: Publications Office of the European Union, p. 13. Available at: https://www.cedefop.europa.eu/files/5559_en.pdf.

13.Cedefop (2018). Insights into skill shortages and skill mismatch. Luxembourg: Publications Office of the European Union, p. 13. Available at: https://www.cedefop.europa.eu/files/3075_en.pdf.

14.Choi, N., \& Majumdar, S. (2014). Social entrepreneurship as an essentially contested concept: Opening a new avenue for systematic future research. Journal of Business Venturing, 29(3), 363-376. DOI:10.1016/j.jbusvent.2013.05.001.

15.Cornali, F., \& Tirocchi, S. (2012). Globalization, education, information and communication technologies: what relationships and reciprocal influences? Procedia - Social and Behavioral Sciences, 47, 2060-2069, DOI:10.1016/J.SBSPRO.2012.06.949.

16.Corner, P.D., \& Ho, M. (2010). How Opportunities Develop in Social Entrepreneurship. Entrepreneurship Theory and Practice, 34(4), 635-659. https://doi.org/10.1111/j.1540-6520.2010.00382.x.

17.Dees, J.G. (2001). The Meaning of Social Entrepreneurship. pp.1-5. Available at: https://centers.fuqua.duke.edu/case/wpcontent/uploads/sites/7/2015/03/Article Dees MeaningofSocialEn trepreneurship_2001.pdf.

18.DEX (2020). Education definitions. Available at: https://dexonline.ro/definitie/educatie.

19.Drucker, P.F. (2011). Management challenges for the 21st Century (2nd Edition ed.). London: Routledge, p. $12, \quad$ ISBN: $0750685093 \quad 9780750685092 . \quad$ Available at: https://www.abebooks.com/9780750685092/Management-Challenges-21st-Century-Classic0750685093/plp.

20.Edgerton, J.D., Roberts, L.W., \& von Below, S. (2012). Education and Quality of Life. In D. 10.1007/97894-007-2421-1_12 (Ed.), Handbook of Social Indicators and Quality of Life Research. Springer Science and Business Media, p. 265-296, ISBN 978-94-007-2421-1. Available at: https://doi.org/10.1007/978-94007-2421-1.

21.Elsby, M., Michaels, R., \& Ratner, D. (2015). The Beveridge Curve: A Survey. Journal of Economic Literature, 53(3), 571-630. DOI:10.1257/jel.53.3.571.

22.European Commission (2010). EUROPE 2020: A European strategy for smart, sustainable and inclusive growth. Brussels, p. $3 . \quad$ Available at: https://ec.europa.eu/eu2020/pdf/COMPLET\%20EN\%20BARROSO\%20\%20\%20007\%20\%20Europe\%2 02020\%20-\%20EN\%20version.pdf.

23.European Commission (2012). Rethinking Education: Investing in skills for better socio-economic outcomes. Strasbourg: European Commission, p. 17. Available at: https://www.cedefop.europa.eu/files/com669 en.pdf. 
24.European Commission (2014). Entrepreneurship Education: A Guide for Educators. Brussels: Entrepreneurship 2020 Unit; Directorate-General for Enterprise and Industry and European Commission, pp. 60-63. DOI: $10.2769 / 51003$.

25.European Commission (2017). European Semester Thematic Factsheet: Skills for The Labour Market, p. 4. Available at: https://ec.europa.eu/info/sites/info/files/european-semester_thematic-factsheet_skills-forlabour-market en 0.pdf.

26.European Commission (2018). Romania country report. Bruxelles, p. 2. Available at: https://ec.europa.eu/info/sites/info/files/2018-european-semester-country-report-romania-ro.pdf.

27.European Commission (2020a). Romania country Report. Brussels, p. 34. Available at: https://eurlex.europa.eu/legal-content/EN/TXT/PDF/?uri=CELEX:52020SC0522\&from=EN.

28.European Commission (2020b). Social Enterprises and their Ecosystems in Europe. Available at: file://C:/Users/Student/Downloads/Social\%20enterprises\%20and\%20their\%20ecosystems\%20in\%20Eur ope.\%20Comparative\%20synthesis\%20report.pdf.

29.Eurostat statistics explained (2019). Distribution of the population aged 25-64 years by level of educational attainment, 2018. Available at: https://ec.europa.eu/eurostat/statisticsexplained/index.php?title=File:QOL19-Edu-Fig01-new.png.

30.Eurostat statistics explained (2019). Proportion of the population aged 25-64 years with a tertiary level of educational attainment, 2008 and 2018. Available at: https://ec.europa.eu/eurostat/statisticsexplained/index.php?title=File:QOL19-Edu-Fig02-new.png.

31.Eurostat statistics explained (2019). Quality of life indicators - education. Available at: https://ec.europa.eu/eurostat/statistics-explained/index.php?title=Quality of life indicators - education.

32.Eurostat statistics explained (2020). Beveridge curve, 2006q4 to 2019q4 (four-quarter average rates). Available https://ec.europa.eu/eurostat/statisticsexplained/index.php?title=File:Beveridge_curve,_2006q4_to_2019q 4 (four-quarter average rates).png.

33.Eurostat statistics explained (2020). Distribution of employment by enterprise size class, 2017 (\%). Available https://ec.europa.eu/eurostat/statisticsexplained/index.php?title=File:Distribution_of_employment_by_ent erprise_size_class,_2017_(\%25).png.

34.Eurostat statistics explained (2020). Entrepreneurship - statistical indicators. Available at: https://ec.europa.eu/eurostat/statistics-explained/index.php/Entrepreneurship - statistical indicators.

35.Eurostat statistics explained (2020). The employment share of high growth enterprises in 2017 (\%). Available https://ec.europa.eu/eurostat/statisticsexplained/index.php?title=File:The employment share of high gr owth enterprises in 2017 (\%25).png.

36.Eurostat statistics explained (2020). Unemployment rates, seasonally adjusted, December 2019. Available at:https://ec.europa.eu/eurostat/statisticsexplained/index.php?title=File:Unemployment_rates,_seasonally adjusted, December 2019.png.

37.Forbes (2019). Bill Drayton and Social Entrepreneurship: How a Social Movement is Changing the World... and Launching Another: EVERYONE A CHANGEMAKER, 22.11.2019. Available at: https://www.forbes.com/sites/williammeehan/2019/11/22/bill-drayton-and-social-entrepreneurship-howasocial-movement-is-changing-the-worldand-launching-another-everyone-achangemaker/\#65bdc31a45de.

38.Fowler, A. (2000). NGDOs as a moment in history: beyond aid to social entrepreneurship or civic innovation? Third World Quarterly, 21(4), 637-654. DOI:10.1080/713701063.

39. Ghaffarzadegan, N., Xue, Y., \& Larson, R. (2017). Work-Education Mismatch: An Endogenous Theory of Professionalization. European Journal of Operational Research, 261(3), 1085-1097. DOI:10.1016/j.ejor.2017.02.041.

40.Green, F. (2016). Skills Demand, Training and Skills Mismatch: A Review of Key Concepts, Theory and Evidence. London: Government Office for Science, p.16. Available at: https://assets.publishing.service.gov.uk/government/uploads/system/uploads/attachment data/file/571667 /ER4_Skills_Demand_Training_and_Skills_Mismatch_A_Review_of_Key_Concepts_Theory_and_Ev idence.pdf.

41.Gupta, P., Chauhan, S., Paul, J., \& Jaiswal, M.P. (2020). Social entrepreneurship research: A review and future research agenda. Journal of Business Research, 113, 209-229, DOI:10.1016/j.jbusres.2020.03.032.

42.Hoek, M. (2018). The Trillion Dollar Shift: Achieving the Sustainable Development Goals. London: Routledge, pp. 432. https://doi.org/10.4324/9781351107297. 
43.Hossain, S., Saleh, M.A., \& Drennan, J. (2017). A critical appraisal of the social entrepreneurship paradigm in an international setting: A proposed conceptual framework. International Entrepreneurship and Management Journal, 13, 347-368. DOI:10.1007/s11365-016-0400-0.

44.Huda, M., Qodriah, S. L., Rismayadi, B., Hananto, A., Kardiyati, E.N., Ruskam, A., \& Nasir, B.M. (2019). Towards cooperative with competitive alliance: insights into performance value in social entrepreneurship. In Creating business value and competitive advantage with social entrepreneurship. IGI Global, pp. 294-317, DOI:10.4018/978-1-5225-5687-9.ch014.

45.International Labour Organization (2019). Quick guide on interpreting the unemployement rate. Geneva: International Labour Office, p. 13. Available at: https://ilo.org/wcmsp5/groups/public/---dgreports/--stat/documents/publication/wcms_675155.pdf.

46.International Labour Organization (2020). World Employment and Social Outlook: Trends 2020. Geneva: International Labour Office, p. 21. Available at: https://www.ilo.org/wcmsp5/groups/public/---dgreports/--dcomm/---publ/documents/publication/wcms_734455.pdf.

47.Kabir, M.N. (2019). Knowledge-Based Social Entrepreneurship. Understanding Knowledge Economy, Innovation, and the Future of Social Entrepreneurship. New York: Palgrave Macmillan, p. 14. ISBN 9781-137-34809-8. Available at: https://doi.org/10.1057/978-1-137-34809-8.

48.Layard, R., Nickell, S., \& Jackm, R. (2005). Unemployment: Macroeconomic Performance and the Labour Market. New York: Oxford University Press, p. 26. DOI:10.1093/acprof:oso/9780199279166.001.0001.

49.Letts, C.W., Brown, L.D., \& Alvord, S.H. (2003). Social Entrepreneurship: Leadership that Facilitates Societal Transformation-An Exploratory Study. Working papers: Center for Public Leadership, pp. 135-159. Available at: http://hdl.handle.net/1721.1/55803.

50.Mars, M.M., Slaughter, S., \& Rhoades, G. (2008). The state-sponsored student entrepreneur. Journal of Higher Education, 79(6), 638-670. DOI:10.1353/jhe.0.0024.

51.Martínez-Torres, M.R. (2014). Analysis of open innovation communities from the perspective of social network analysis. Technology Analysis \& Strategic Management, 26(4), 435-451. DOI:10.1080/09537325.2013.851378.

52.McCann, P., \& Ortega-Argiles, R. (2013). Modern regional innovation policy. Cambridge Journal of Regions, Economy and Society, 6(2), 187-216. Available at: https://EconPapers.repec.org/RePEc:oup:cjrecs:v:6:y:2013:i:2:p:187-216.

53.Mulgan, G. (2006). The process of social innovation. Innovations: Technology, Governance, Globalization, 1(2), 145-162. Available at: https://EconPapers.repec.org/RePEc:tpr:inntgg:v:1:y:2006:i:2:p:145-162.

54.Newey, L.R. (2018). Changing the system: Compensatory versus transformative social entrepreneurship. Journal of Social Entrepreneurship, 9(1), 13-30. https://doi.org/10.1080/19420676.2017.1408671.

55.Nicholls, A. (2006). Social Entrepreneurship: New Models of Sustainable Change. Oxford, UK: Oxford University Press. Available at: smd.ac.id/files/Perpustakaan_Digital_1/ENTREPRENEURSHIP\%20Social\%20entrepreneurship,\%20Ne w\%20m.pdf.

56.Nolan, P. \& Coghlan, D. (2002). Confronting long-term unemployment through social entrepreneurship: An action research study. Concepts and Transformation, 7(3), 277-299. https://doi.org/10.1075/cat.7.3.05nol.

57.Noruzi, M.R., Westover, J.H., \& Rahimi, G.R. (2010). An Exploration of Social Entrepreneurship in the Entrepreneurship Era. Asian Social Science, 6(6), 3-10. Available at: http://www.ccsenet.org/journal/index.php/ass/article/download/6217/4893.

58.OECD (2010). Social Entrepreneurship and Social Innovation. In SMEs, Entrepreneurship and Innovation, OECD publications, p. $196 . \quad$ Available at: http://ec.europa.eu/DocsRoom/documents/14506/attachments/22/translations/en/renditions/native.

59.OECD (2013). Job Creation through the Social Economy and Social Entrepreneurship. Available at: https://www.oecd.org/cfe/leed/130228 Job\%20Creation\%20throught\%20the\%20Social\%20Economy\%2 0and\%20Social\%20Entrepreneurship_RC_FINALBIS.pdf.

60.OECD (2017). Future of work and skills. p. 9. Available at: https://www.oecd.org/els/emp/wcms_556984.pdf.

61.Okpara, J.O., \& Halkias, D. (2011). Social entrepreneurship: an overview of its theoretical evolution and proposed research model. International Journal of Social Entrepreneurship and Innovation, 1(1), 4-20. Available at: https://doi.org/10.1504/IJSEI.2011.039808.

62.Pangriya, R. (2019). Hidden aspects of social entrepreneurs' life: a content analysis. Journal of Global Entrepreneurship Research, 9(66), 2-19. https://doi.org/10.1186/s40497-019-0199-6. 
63.Pârgaru, I., Gherghina, R., \& Duca, I. (2009). The role of education in the knowledge-based society during the economic crisis. Annales Universitatis Apulensis Series Oeconomica, 11(2), 646-651. Available at: http://www.oeconomica.uab.ro/upload/lucrari/1120092/04.pdf.

64.Phillips, W., Lee, H., Ghobadian, A., O’Regan, N., \& James, P. (2014). Social Innovation and Social Entrepreneurship: A Systematic Review. Group \& Organization Management, 40(3), 428-461. https://doi.org/10.1177/1059601114560063.

65.Rahim, H.L. \& Lajin, N.F.M. (2015). Social entrepreneurship and graduate employability. International Academic Research Journal of Social Science, 1(1), 33-40. Available at: https://www.researchgate.net/profile/HardyRahim/publication/280325817 Social Entrepreneurship and Graduate_Employability/links/55b31e1b08aed621ddfe17d5/Social-Entrepreneurship-and-GraduateEmployability.pdf.

66.Saebi, T., Foss, N.J., \& Linder, S. (2018). Social Entrepreneurship Research: Past Achievements and Future Promises. Journal of Management, 45(1), 70-95. https://doi.org/10.1177/0149206318793196.

67.Shaw, E., \& Carter, S. (2007). Social entrepreneurship: Theoretical antecedents and empirical analysis of entrepreneurial processes and outcomes. Journal of Small Business and Enterprise Development, 14(3), 418-434. Available at: http://dx.doi.org/10.1108/14626000710773529.

68.Shaw, E., \& de Bruin, A. (2013). Reconsidering capitalism: the promise of social innovation and social entrepreneurship? International Small Business Journal, 31(7), 737-746. https://doi.org/10.1177/0266242613497494.

69.Slijepcevic, D. (2016). Education as a mechanism of social inclusion. The role of education in reducing the risks of social exclusion. Sociological discourse, 6(11), 93-108. DOI:10.7251/SDENG1611093S.

70.Tan, W.L., Williams, J.N., \& Tan, T.M. (2005). Defining the 'Social' in 'Social Entrepreneurship': Altruism and Entrepreneurship. International Entrepreneurship and Management Journal, 1(3), 353-365. https://doi.org/10.1007/s11365-005-2600-x.

71.Toma, S.-G., Grigore A.M., \& Marinescu, P. (2014). Economic development and entrepreneurship. Procedia. Economics and Finance, 8, 436-443. Available at: https://core.ac.uk/download/pdf/82660826.pdf.

72.UNESCO, OECD and EUROSTAT (2018). Data Collection on formal education Manual on concepts, definitions and classifications, p. $5 . \quad$ Available at: http://uis.unesco.org/sites/default/files/documents/uoe2016manual_11072016_0.pdf.

73.UNESCO (2012). International Standard Classification of education ISCED 2011. Montreal: UNESCO Institute for Statistics, pp. 25-59. Available at: http://uis.unesco.org/sites/default/files/documents/international-standard-classification-of-educationisced2011-en.pdf.

74.Walper, R. (2003). Unemployment, Market Structure and Growth. Berlin: Springer-Verlag Berlin Heidelberg, pp. 63-95, ISBN 978-3-642-55893-1. Available at: https://www.springer.com/us/book/9783540404491.

75.Zahra, S.A., Newey, L.R., \& Li, Y. (2014). On the Frontiers: The Implications of Social Entrepreneurship for International Entrepreneurship. SAGE Journals: Entrepreneurship Theory and Practice, 38(1), 137-158. https://doi.org/10.1111/etap.12061.

76.Zainea, L.N., Marinescu, P., \& Tohanean, D. (2019). Volunteering, A Key Factor to Increase the Employment Rate, in the European Context. Manager Journal, 30(1), 181-190, Available at: https://EconPapers.repec.org/RePEc:but:manage:v:30:y:2019:i:1:p:181-190.

77.Zainea, L.N., Toma, S.-G., Gradinaru, C., \& Catana, S. (2020). Social entrepreneurship, a key driver to improve the quality of life: The case of TOMS Company. Business Ethics and Leadership, 4(3), 65-72. Available at: https://armgpublishing.sumdu.edu.ua/wp-content/uploads/2020/10/6-2.pdf.

78.Waghid, Z., \& Oliver, H. (2017). Cultivating social entrepreneurial capacities in students through film: Implications for social entrepreneurship education. Educational Research for Social Change, 6(2), 76-100. Available at: http://www.scielo.org.za/pdf/ersc/v6n2/07.pdf. 